\title{
Three Western-Mineral-Resources Archives
}

\begin{abstract}
$\mathrm{M}$ eeting the challenge of balancing America's needs for both nonrenewable resources and a clean, healthy environment requires accurate and unbiased scientific data. The ongoing work of U.S. Geological Survey (USGS) scientists provides information crucial to the creation of sound public policies that will ensure future supplies of mineral resources while protecting the health of our Nation's citizens. Three archives, in Anchorage, Alaska, Spokane, Washington, and Tucson, Arizona, are maintained by the USGS to help policymakers, industry leaders, government officials, elected representatives, and the general public make informed decisions on mineral issues based on accurate, up-to-date, and impartial mineral-resource information.
\end{abstract}

\section{Alaska Technical Data Unit}

In 1896, three men discovered gold on the Klondike River in the Yukon Territory of Canada. When news of the discovery reached the outside world in the summer of 1897 , thousands of men and women began a great rush to the Yukon Territory and Alaska. In January 1898, Congress appropriated funds for the U.S. Geological Survey (USGS) to make geologic and topographic surveys in Alaska. As geologists made plans for fieldwork, Walter C. Mendenhall wrote in a letter to Alfred $\mathrm{H}$. Brooks:

Interest here among a good many of the younger men is centered in the Alaskan plans which Mr. Willis and the Director are considering at present. The bill appropriating $\$ 20,000$ was signed by the president a week or more ago. This with the unexpended appropriation of $\$ 5,000$ made last year gives them a good working sum. The plan being considered at present involves the

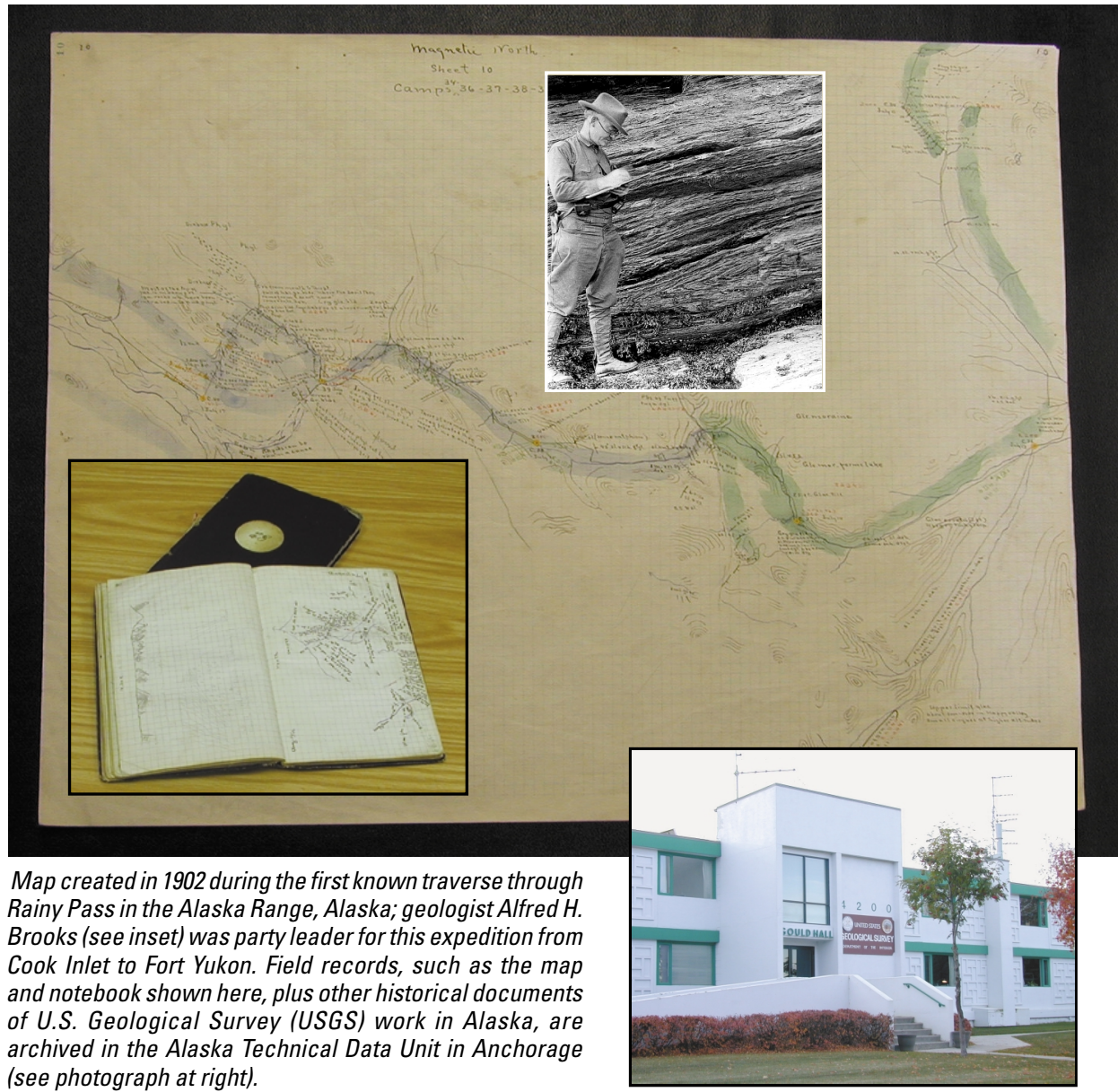

sending in of four or five different parties, each in charge of a geologist and accompanied by a topographer and several camp hands. The tendency seems to be to choose pretty big men to put in charge of these parties. Spurr, of course, will have charge of one. Keith has been offered another, and will probably take it if he can agree with the Director upon the time of starting. He thinks that he cannot be ready before the first of May, while the parties are expected to start at least a month earlier. Eldridge has been mentioned for another, but I believe that the matter has not been broached to him yet, unless it was brought up yesterday. It was hoped at one time that I.C. Russell might be willing to take a command, but I don't know whether he has been communicated with or not. Schrader rather put himself out of the game earlier, when he thought there would be nothing open to him but an assistantship, by expressing a preference for work in the States. I think that if an independent party were offered him under the new plans, he would take it, and I should not wonder if one were offered him. I am sorry that Hayes is not here, for there is no doubt that he would be given an opportunity to carry out some of his cherished plans for exploration there. Your own application is being considered, but I do not know what your chances are. I think, though, pend in some measure upon the attitude of the more experienced geologists. Several of these latter will be offered parties first; if they don't want them, the boys may be given a chance. I applied some time since for a transfer to that the chances of the younger men de- 
the West and took the occasion to mention that I was in a receptive mood so far as Alaska was concerned. B.W. [Bailey Willis?] called me up the other day and told me confidentially that he didn't think that I had a ghost of a show to get an Alaskan assignment, since something would be required there besides a superabundance of W.Va. experience. I told him that that was all right but I should like to have some assurance that the W.Va. dose was not to be unnecessarily prolonged. He made me happy by saying that I should be sent west this summer, perhaps with Smith in northern Washington. Other plans will not be touched, of course, until the Alaskan assignments are settled, but Tom Reed and some others have set their faces toward an early adjournment of congress, hence there seems to be some ground for hope that the regular appropriation will not drag along until long after July $1^{\text {st }}$, as it usually does with a new congress.

As it turned out, both Brooks and Mendenhall realized their ambitions that year, each leading a field party to Alaska, along with the aforementioned Spurr, Eldridge, and Schrader. Brooks continued to work in Alaska and served as head of Alaskan operations from 1903 until his death in 1924.

Mendenhall returned for three more field seasons (1900-2) and eventually served as Director of the U.S. Geological Survey from 1931 until 1943.

Mendenhall's letter is just one of the historical records preserved in the Alaska Technical Data Unit (ATDU) in Anchorage, Alaska. ATDU is the archive of original geologic field notes, maps, correspondence, and unpublished reports that document the history of USGS work in Alaska. The two major categories of reference materials are the Project History files and the Geologic Subject files.

The Project History files encompass much of the raw data from which the Federal geologic maps of Alaska have been compiled. These files include:

- Geologic notebooks containing the original field observations, descriptions, and sketches by USGS geologists working in Alaska since 1891. More than 3,700 notebooks are arranged in numerical order and are indexed in a computerized data base. Microfilms of these notebooks are also available for onsite use at the USGS in Menlo Park, California.

- Map files containing more than 850 sets of original field sheets and sketch maps, map compilations, cross sections, diagrams, and annotated aerial photographs. These materials are arranged by quadrangle and are also indexed in a computerized data base.

- Paleontological notebooks containing fossil identifications made at various localities in Alaska since 1898. These notebooks are arranged by year of collection, and there is no index for this record group.

- Petrographic thin sections made from rock samples collected in the field for analysis and description. More than 30,000 sections are indexed by year and collector.

The Geologic Subject files incorporate more than 6,500 files containing unpublished reports, speeches and lectures, correspondence, reprints, photographs, and historical materials relating to USGS activities in Alaska. Also included are some reports by the Alaska Power Authority and the U.S. Atomic Energy Commission, handwritten translations of Russian geologic texts, and a small collection of Alaskan military terrain studies and highway reports. These files are indexed under 31 subject headings in a computerized data base.

The Economic Mineral files are a subset of the Geologic Subject files that pertain to mineral resources, mineral commodities, and mining activities in Alaska. These files contain news clippings, company reports, mine histories and production summaries, and USGS evaluations of "strategic mineral" properties for the Defense Minerals Administration and its successors.

Digital catalogs of the materials in ATDU have been compiled, utilizing desktop PC's and the Microsoft Access relational-database software, running in a Windows NT environment. Access to this archive is by appointment only; written and electronic requests are also accepted. Researchers should first conduct a thorough search of the published literature to determine which scientists have worked in their area of interest and whose notes and maps might be most useful to them. Access to certain materials may be restricted for nongovernmental employees. Owing to the irreplaceable nature of items in ATDU, only copies will be supplied, and reproduction costs will be born by the requestor. For further information, call or write to:
Jill Schneider
Technical Data Unit
U.S. Geological Survey
4200 University Drive
Anchorage, AK 99508-4667
Telephone: (907) 786-7457
Fax: (907) 786-7401
E-mail: jschnidr@usgs.gov

\section{Property Files from Federal Government Exploration-Assistance Programs (1950-74)}

In 1950, Congress enacted the Defense Production Act, which authorized the President to make provision for the encouragement of exploration, development, and mining of critical and strategic minerals, metals, and materials.The President delegated his authority to the Department of the Interior, among other agencies, and the Secretary of the Interior established the Defense Minerals Administration (DMA). One of the purposes of the DMA was to provide Government support for exploration of unknown or undeveloped mineral deposits. To this end, the DMA established a program that would provide funds for projects which sought or developed sources of strategic or critical metals and minerals. When the DMA was terminated in November 1951, the Department of the Interior formed the Defense Minerals Exploration Administration (DMEA) and continued the program until June 1958. In August of that year, Congress enacted a law that authorized the Secretary of the Interior to provide financial assistance which would promote exploration for domestic mineral reserves, and the Secretary formed the Office of Minerals Exploration (OME). In 1965, OME was transferred to the USGS, where it remained until Congress terminated funding in 1974. Contracts with these agencies provided financial assistance for exploration on a joint-participation basis.

These contracts are documented in 


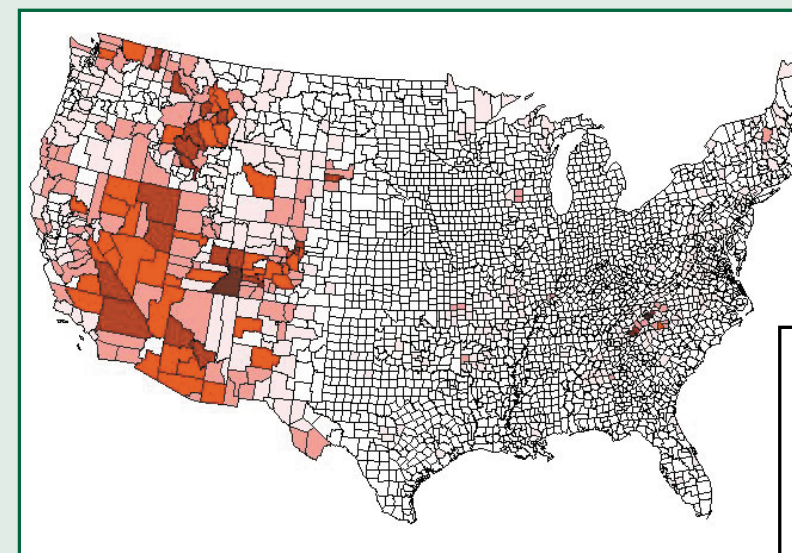

Map showing distribution of properties in the lower 48 states for which documents are available for inspection at the U.S. Geological Survey (USGS) Field Office in Spokane, Washington (housed in building shown in photograph at right).

The master set of dockets from the Defense Minerals Administration, Defense Minerals Exploration Administration, and Office of Minerals Exploration occupy 480 cubic feet in the USGS Spokane Field Office (below).
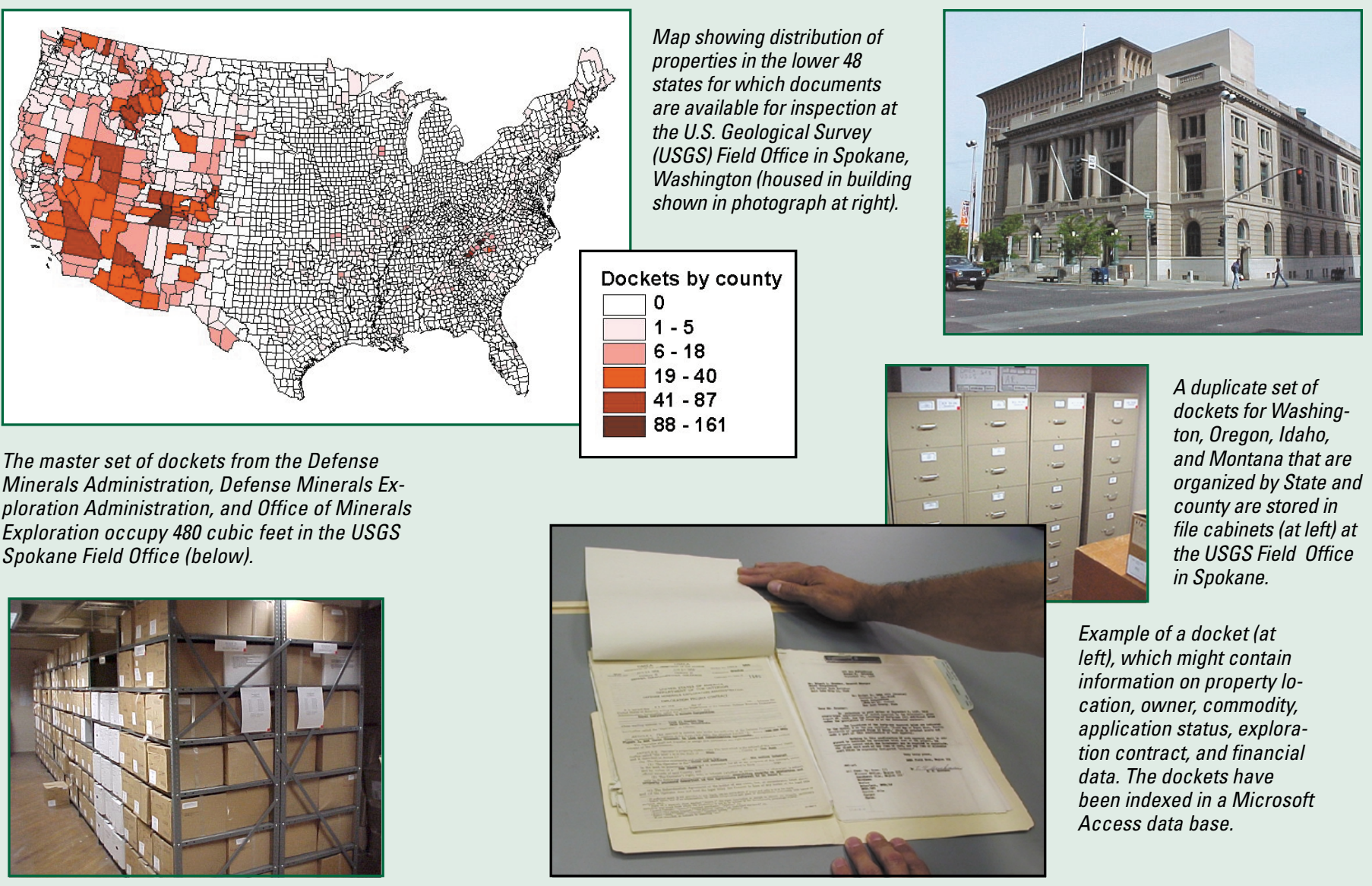

A duplicate set of dockets for Washington, Oregon, Idaho, and Montana that are organized by State and county are stored in file cabinets (at left) at the USGS Field Office in Spokane.

Example of a docket (at left), which might contain information on property location, owner, commodity, application status, exploration contract, and financial data. The dockets have been indexed in a Microsoft Access data base.

over 5,000 property files (called "dockets") generated by the DMADMEA-OME exploration-assistance programs. The first item in most dockets is the property owner's program application, which would contain information concerning the property's location, commodity to be pursued, and funds requested. This should be followed by a site evaluation and recommendation. Additional reports might detail the status of the application, specifics of any financial contract awarded, results of exploration, production summaries, payback schedules, interim evaluations, and contractcompletion data. The dockets reflect program activities carried out in 44 States; only Delaware, Indiana, Nebraska, North Dakota, Ohio, and Rhode Island are not represented.

Until 1996, these dockets were stored at several locations throughout the United States. In the spring of that year, they were consolidated into the DMA-DMEA-OME Archive, located in the USGS Spokane Field Office. The integrated collection occupies approximately 480 cubic feet and has been indexed in a Microsoft Access data base. Interested parties may access dockets at the Spokane office or make arrangements to have them copied for offsite inspection.

The Spokane Field Office also archives many project files of the former U.S. Bureau of Mines, as well as the office files of several Bureau geologists who did mineral-resource studies.

For further information about the exploration-assistance files and other archival materials at the USGS Field Office in Spokane, call or write to:

Dave Frank

U.S. Geological Survey

West 904 Riverside Avenue

Spokane, WA 99201-1087

Telephone: (509) 368-3107

Fax: (509) 368-3199

E-mail: dfrank@usgs.gov

\section{Latin American Archive}

From 1989 until 1995, the USGS operated the Center for Inter-American Mineral Resource Investigations (CIMRI) in Tucson, Arizona. This center served as a focal point for the development and exchange of minerals information between public mineral-resources agencies and the mining industry in the Americas. The USGS, through CIMRI, actively sought to develop cooperative working relationships among governments, organizations, and individuals interested in the mineral resources of Latin America and the Caribbean region. CIMRI undertook four basic interrelated activities to accomplish its mission: (1) development and exchange of minerals information, (2) cooperative mineral-resource investigations, (3) technology transfer and training, and (4) research.

CIMRI collected and disseminated published and unpublished information on the mineral resources of Latin America. Much of this information was archived for public inspection. This archive includes maps, files, reports, bibliographies, computerized data bases, and many related materials.

In 1995, CIMRI was abolished; however, the archive remains. This eclectic, multilingual collection is 


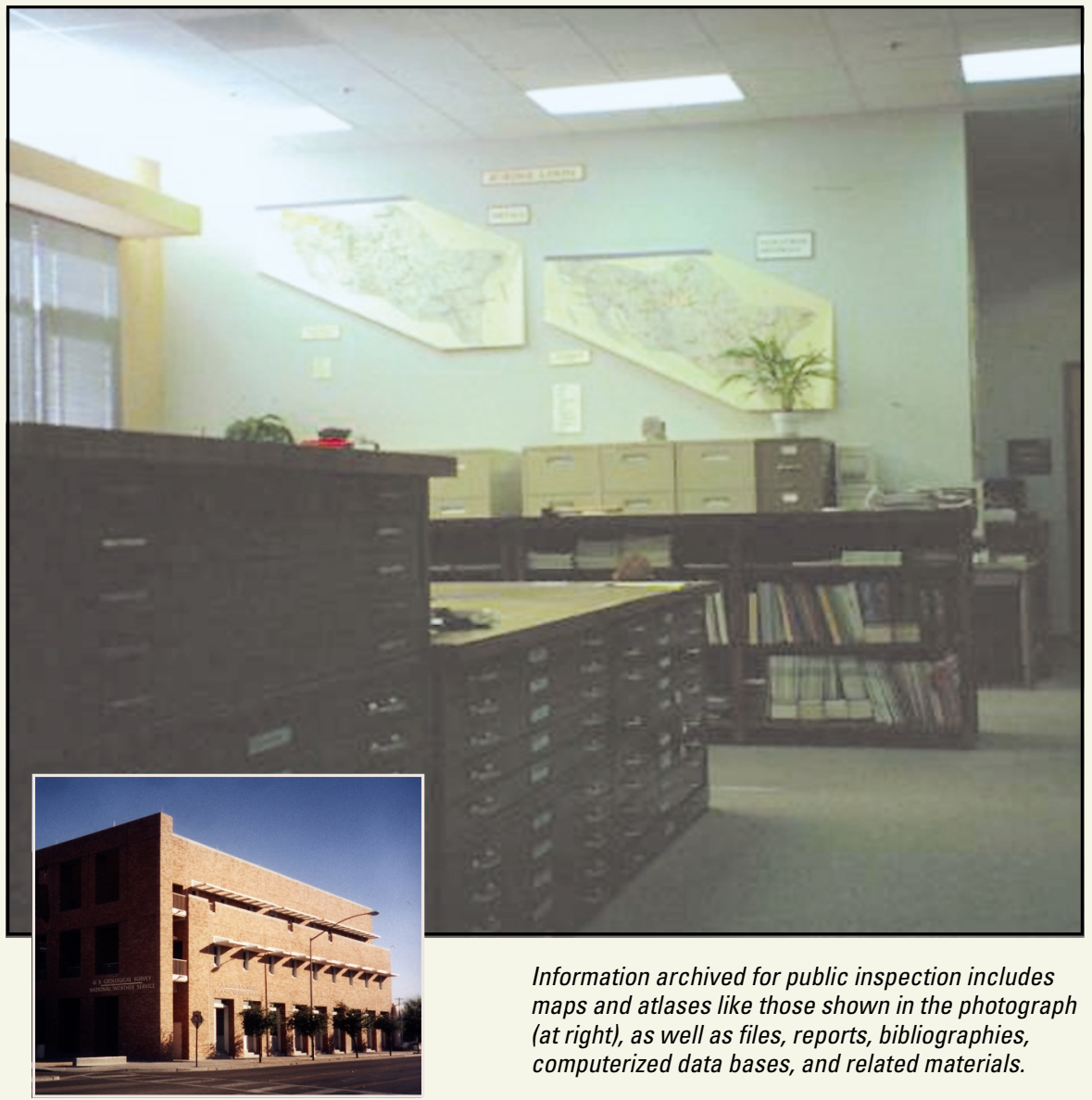

organized by country and consists largely of "gray literature," unpublished or difficult-to-obtain reports that would not be easily available in most libraries. The archive is open to the public from 8:00 a.m. until 4:00 p.m., Monday through Friday, and is used by researchers from around the world who are interested in the mineral resources of Latin America.

The Latin American archive, located in the Environment and Natural Resources Building on the University of Arizona campus, currently consists of approximately 55 linear feet of materials housed in file cabinets, an additional 61 feet on shelves, and 39 drawers of maps. It includes such materials as The Mineral Deposits of Peru, an unpublished 1,715-page manuscript and more than 300 accompanying maps by former USGS geologist Frank Simons, who worked in Peru; and the Latin American portion of the field notes and correspondence of V.F. Hollister, a consultant who worked throughout the Americas.

To receive further information about the Latin American archive or to make arrangements to visit, call or write to:

Karen Sue Bolm

U.S. Geological Survey

520 North Park Avenue, Suite 355

Tucson, AZ 85719-5035

Telephone: (520) 670-5544

Fax: (520) 670-5113

E-mail: kbolm@usgs.gov

These three archives are maintained by the U.S. Geological Survey to help our officials and the public to make
The U.S. Geological Survey (USGS) Latin American Archive (to left), located in the Environment and Natural Resources Building on the University of Arizona campus in Tucson, Arizona (below left), currently consists of approximately 55 feet of materials housed in file cabinets, an additional 61 feet on shelves, and 39 drawers of maps. This archive of the Center for Inter-American Mineral Resource Investigations includes such materials as The Mineral Deposits of Peru, an unpublished 1,715page manuscript and more than 300 accompanying maps by former USGS geologist Frank Simons, who worked in Peru; and the Latin American portion of the field notes and correspondence of V.F. Hollister, a consultant who worked throughout the Americas.

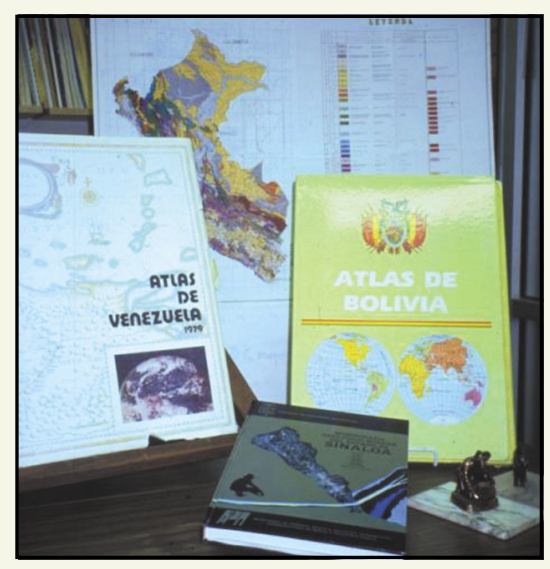

informed decisions based on accurate and impartial mineral resource information. Keeping our environment healthy and supplying America's need for nonrenewable resources requires unbiased scientific data. The availability of these data is crucial for the creation of sound public policies. USGS scientists are providing important information, now and for the future, that will keep our environment healthy and protect our Nation citizens.

Karen Bolm, Dave Frank, and Jill L. Schneider

Graphic design by Judy Weathers

For more information contact:
The Spokane Field Office
U.S. Geological Survey
904 W. Riverside Ave., Room 202
Spokane, Washington 99201-1087
Telephone (509) 368-3101
Fax (509)368-3199

Any use of trade, product, or firm names in this publication is for descriptive purposes only and does not imply endorsement by the U.S. Government 